\title{
p53 protein regulates the effects of amifostine on apoptosis, cell cycle progression, and cytoprotection
}

\author{
EJ Lee ${ }^{1,2}$, M Gerhold', MW Palmer' and RD Christen*,I \\ 'Department of Medicine and Cancer Center, 0058, University of California San Diego, 9500 Gilman Drive, La Jolla, CA 92093-0058, USA; \\ ${ }^{2}$ Department of Oral Pathology, Oral Cancer Research Institute, Yonsei University College of Dentistry, 134 Shinchon-Dong, Seaodaemun-ku, Seoul, 120 - \\ 752, Korea
}

To determine the role of p53 protein on the cellular effects of amifostine, we used molecularly engineered HCTI I6 colon cancer cells in which the p53 gene was inactivated by targeted homologous recombination or p53 protein was degraded by high-level expression of papillomavirus 66 protein. Amifostine induced a GI arrest and protected against paclitaxel toxicity in p53-proficient but not in p53-deficient cells. In the absence of p53 protein, amifostine enhanced the cytotoxicity of paclitaxel. In addition, treatment of HCTI 16 cells with amifostine alone resulted in apoptotic cell death. Compared with p53-deficient cells, p53-proficient cells exhibited low-level resistance to amifostine-induced apoptosis. Amifostine induced the expression of p53 protein in p53-proficient cells and the expression of $\mathrm{p} 2 \mathrm{I}$ protein in both p53-proficient and -deficient cells. These findings indicate that amifostine-induced GI arrest and cytoprotection are mediated via a pathway that is dependent on p53 protein and that amifostine-induced expression of p2 1 protein is not sufficient to sustain a GI arrest or to mediate cytoprotection. In addition, these findings identify p53 protein as a mechanism of resistance to amifostine-induced apoptosis.

British Journal of Cancer (2003) 88, 754-759. doi: I0.1038/sj.bjc.6600779 www.bjcancer.com

(C) 2003 Cancer Research UK

Keywords: amifostine; p53 protein; p2I protein; cell cycle arrest; apoptosis; cytoprotection

Amifostine, designated WR-2721, was originally synthesised at the Walter Reed Army Institute of Research in the 1950s to protect military personnel from nuclear radiation. Amifostine protects cells from cytotoxic damage by scavenging oxygen-free radicals caused by radiation and radiomimetic drugs and by binding to reactive nucleophiles, which have the potential to react with DNA (van der Vijgh and Peters, 1994).

Amifostine has demonstrated broad-spectrum cytoprotection against myelotoxicity, nephrotoxicity, xerostomia, and mucositis associated with various chemotherapy and radiation regimens (Capizzi and Oster, 2000). Large comparative clinical trials of amifostine in patients with advanced ovarian cancer (Kemp et al, 1996), rectal cancer (Liu et al, 1992), and head and neck cancer (Brizel et al, 2000) have been completed. These trials have shown that amifostine protects against the cytotoxic effects of cisplatin, cyclophosphamide, and radiation therapy. In addition, amifostine protects against xerostomia in patients with head and neck cancer treated with radiation therapy and in patients with thyroid cancer treated with high-dose radio-iodine (Bohuslavizki et al, 1998; Buntzel et al, 1998). Recent observations also indicate that amifostine improves cytopenia in patients with myelodysplastic syndromes (List et al, 1997, 1998).

WR-1065, the active metabolite of amifostine, protects cells from cytotoxic damage by scavenging oxygen-free radicals generated by radiation and anthracyclines and by binding to highly reactive nucleophiles and thus preventing nucleophiles from reacting with

*Correspondence: Dr Randolph Christen; E-mail: rchristen@ucsd.edu Received 20 May 2002; revised 18 November 2002; accepted 22 November 2002
DNA (Treskes and van der Vijgh, 1993). The sulphydryl group of WR-1065 inactivates carbonium ions generated by alkylating agents and thereby prevents the formation of DNA crosslinks (DeNeve et al, 1988). Amifostine also protects against the cytotoxicity of paclitaxel, a cytoprotective effect that is not readily explained (Taylor et al, 1997).

In addition to its cytoprotective properties, amifostine has other interesting biologic effects. For instance, WR-1065 reduces the level of phosphorylation and inhibits the enzymatic activity of topoisomerase II (Grdina et al, 1994; Murley et al, 1997; Snyder and Grdina, 2000). Amifostine and its metabolite upregulate genes involved in cell proliferation, including $c-m y c$ and thymidine kinase (Woloschak et al, 1995; Liu et al, 1997). In mouse fibroblasts and breast cancer cells, amifostine and its metabolite WR-1065 have been shown to activate p53 protein, to induce the expression of the cyclin-dependent kinase inhibitor p21, and to arrest cells at the G1/S transition via a p53-dependent pathway (North et al, 2000). In addition, amifostine binds to the transcription factors nuclear factor- $\kappa \mathrm{B}$, activator protein-1, and p53 protein, resulting in enhanced binding of these proteins to target regulatory DNA sequences and subsequent transactivation of downstream genes (Shen et al, 2001). Similarly, in a yeast functional assay, amifostine restored the transcriptional activity of p53 mutants (Maurici et al, 2001). In nontransformed cells, WR-1065 protects cells from the cytotoxic effects of paclitaxel in a p53-dependent manner (Shen et al, 2001). However, amifostine had no cytoprotective effect in transformed human tumour cells, suggesting that p53-dependent growth arrest is the basis for the protective effect of amifostine and that this pathway is abrogated in human tumours (Shen et al, 2001). 
In the current study, we used two sets of p53-proficient and -deficient cell lines to determine the effect of p53 protein on amifostine-induced apoptosis, cell cycle arrest, and cytoprotection.

\section{MATERIALS AND METHODS}

\section{Cell lines}

Parental human colon carcinoma HCT116 cells were obtained from the American Type Culture Collection (ATCC, CCL 247). HCT116 cells contain a hemizygous mutation in hMLH1, resulting in a truncated, nonfunctional protein (Boyer et al, 1995). A subline complemented with chromosome 3, designated HCT116+ch3, was obtained from Drs CR Boland and M Koi (Koi et al, 1994). The chromosome 3-complemented cells were competent in DNA mismatch repair (Koi et al, 1994). HCT116 cells in which both p53 alleles were deleted by targeted homologous recombination, designated HCT116/p53 $3^{-1-}$, were obtained from Dr Bert Vogelstein (Bunz et al, 1999). HCT116 cells and HCT116+ch3 expressing papillomavirus E6, designated HCT116/E6 and HCT116+ch3/E6, were obtained from Drs A Boothman and M Meyers. These cell lines constitutively express high levels of human papillomavirus type-16 E6 protein, which stimulates the degradation of p53 protein via an ubiquitin-dependent pathway (Davis et al, 1998). All cell lines were maintained in Iscove's modified Dulbecco's medium (Irvine Scientific, Irvine, CA, USA) supplemented with $100 \mathrm{~mm} \mathrm{~L}-$ glutamine and $10 \%$ heat-inactivated foetal bovine serum. The chromosome-complemented lines were grown in medium supplemented with $400 \mu \mathrm{g} \mathrm{ml}^{-1}$ geneticine (GIBCO BRL, Gaithersburg, $\mathrm{MD}$, USA). HCT $116 / \mathrm{p} 53^{+/+}$and HCT $116 / \mathrm{p} 53^{-I-}$ cells were maintained in McCoy's medium (Irvine Scientific, Irvine, CA, USA) supplemented with $100 \mathrm{~mm}$ L-glutamine and $10 \%$ heatinactivated foetal bovine serum.

\section{Reagents}

Amifostine was obtained from US Bioscience Corporation; a stock solution of $50 \mathrm{mg} \mathrm{ml}^{-1}$ was prepared in $0.9 \% \mathrm{NaCl}$ and stored at $4{ }^{\circ}$ C. Paclitaxel was obtained from Sigma Chemical Co. (St Louis, MO, USA) and was dissolved in DMSO.

\section{Clonogenic assay}

For clonogenic assays, 500 cells were seeded in plastic dishes containing complete media. The cells were allowed to attach overnight, and on the next day, cells were exposed to amifostine at increasing concentrations for $24 \mathrm{~h}$. Thereafter, the cells were washed with PBS and fresh, drug-free medium was added. After $10-14$ days of incubation in humidified $5 \% \mathrm{CO}_{2}$ at $37^{\circ} \mathrm{C}$, cells were washed, fixed with methanol, and stained with $0.1 \%$ crystal violet. Cell clusters containing more than 50 cells were scored as a colony. Each experiment was performed a minimum of three times using triplicate cultures for each drug concentration. $\mathrm{IC}_{50}$ (concentration causing $50 \%$ inhibition of cell growth) values were estimated using log-linear interpolation.

\section{Cell cycle phase distribution}

Approximately $1 \times 10^{6}-2 \times 10^{6}$ cells were exposed to amifostine for $24 \mathrm{~h}$. At various points in time after starting amifostine treatment, cells were harvested, washed twice with ice-cold PBS, and fixed in ice-cold $100 \%$ ethanol. Cells were counted and $10^{6}$ cells per sample were centrifuged, resuspended in $500 \mu$ l of ice-cold PBS, and treated with $0.1 \mathrm{mg} \mathrm{ml}^{-1}$ RNAse A (Sigma Chemical Co.) at $37^{\circ} \mathrm{C}$ for $30 \mathrm{~min}$. Propidium iodide (Molecular Probes, Eugene, OR, USA) at a final concentration of $50 \mu \mathrm{g} \mathrm{ml}^{-1}$ was then added to the cell suspensions. After incubation on ice for $30 \mathrm{~min}$, cells were analysed on a FACScan flowcytometer (Becton-Dickinson, San
Jose, CA, USA). Multicycle AV Cell Cycle software (Phoenix Flow Systems, San Diego, CA, USA) was used to calculate the fraction of cells in each phase of the cell cycle as previously described (Dean and Jett, 1974).

\section{Quantitation of apoptotic cells}

Cells were treated with amifostine for $24 \mathrm{~h}$. At various points in time, floating and attached cells were harvested, centrifuged, resuspended in $100 \mu \mathrm{l}$ of PBS, and stained with acridine orange and ethidium bromide. Subsequently, cells were assessed for apoptotic morphology by supravital fluorescence microscopy. Cells were scored as apoptotic according to established morphologic criteria (McGahon et al, 1995).

\section{Western blot analysis}

Logarithmically growing cells were treated with amifostine for $24 \mathrm{~h}$. At various points in time after the beginning of exposure to amifostine, cells were lysed and proteins extracted in a buffer containing $0.15 \mathrm{M} \mathrm{NaCl}, 5 \mathrm{~mm}$ EDTA. $1 \%$ Triton X-100, $10 \mathrm{~mm}$ TRIS (pH 7.4), 5 mM DTT, $0.1 \mathrm{~mm}$ phenylmethylsulphonyl fluoride, and $5 \mathrm{~mm}$ epsilon-aminocaproic acid. Proteins were quantitated and fractionated by electrophoresis using 7.5 and $15 \%$ polyacrylamide gels (Precast Acrylamide Gels, Bio-Rad, Hercules, CA, USA). Proteins were transferred to polyvinylidene difluoride membranes (Immobilon, Millipore, Bedford, MA, USA). The membranes were blocked with $5 \%$ nonfat milk, $0.05 \%$ Tween for $1 \mathrm{~h}$, washed with $0.05 \%$ Tween and then exposed to primary antibody overnight at $4^{\circ} \mathrm{C}$. Mouse monoclonal anti-p21 (sc-817) and anti-p53 (sc-126) antibodies were obtained from Santa Cruz Biotechnology, Santa Cruz, CA, USA. Primary antibodies were diluted $1: 400$ in $5-10 \%$ nonfat milk. After washing, blots were exposed to horseradish peroxidase-conjugated anti-mouse antibodies (Amersham Life Science, Inc., Arlington Heights, IL, USA) at a dilution of $1: 3000$, and complexes were visualised by enhanced chemiluminescence.

\section{RESULTS}

To investigate how $\mathrm{p} 53$ protein regulates the cellular response to amifostine, we used p53-proficient parental HCT116/p53 $3^{+/+}$and p53-deficient HCT116/p53 ${ }^{-1-}$ cells, in which both $p 53$ alleles were deleted by homologous recombination (Davis et al, 1998). HCT116 cells are genomically instable because of a homozygous mutation at the hMLH1 locus (Koi et al, 1994; Papadopoulos et al, 1994). As a result, HCT116 cells have accumulated multiple mutations, including mutations of the genes encoding the type II receptor for transforming growth factor $\beta 1$, the insulin-like growth factor II receptor, and the proapoptotic gene BAX (Carethers and Pham, 2000). In addition, defective expression of hMLH1 in HCT116 cells results in alterations in the G2/M cell cycle checkpoint following radiation (Hawn et al, 1995). In order to control for spurious effects that are a result of genomic instability and alterations in cell cycle progression, we also used a mismatch repair-proficient HCT116 subline complemented with chromosome 3. HCT116+ch3 cells are genomically stable and have an intact G2/M checkpoint following radiation (Hawn et al, 1995; Carethers and Pham, 2000). In HCT116+ch3 cells, p53 was inactivated by constitutive highlevel expression of the human papillomavirus type 16 E6 gene, which stimulates the degradation of $\mathrm{p} 53$ protein (Davis et al, 1998).

\section{Effect of p53 protein on amifostine toxicity}

Clonogenic assays were used to determine the effect of $\mathrm{p} 53$ protein on the sensitivity of HCT116 colon cancer cells to amifostine (Figure 1). After allowing cells to attach overnight, p53-proficient 


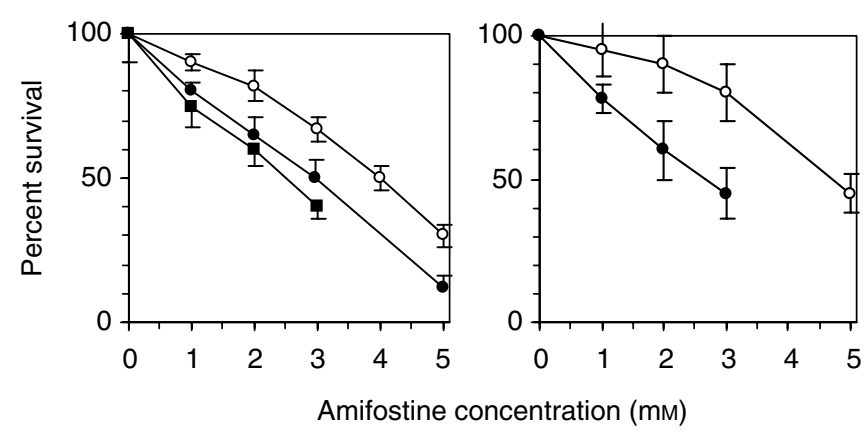

Figure I Effect of p53 protein on amifostine toxicity. HCTII6 cells were exposed to amifostine for $24 \mathrm{~h}$, and dose-response curves were generated by clonogenic assay. Left panel: (O), HCTI I 6/p53 $53^{+/+}$cells; $(\mathbf{O})$, HCTII6/p53 $3^{-1-}$ cells; (ם), HCTII6/E6 cells. Right panel: (O), HCTII6+ch3 cells; $(0)$, HCTII6+ch3/E6 cells. Data points represent mean \pm s.d. of at least three independent experiments performed with triplicate cultures.
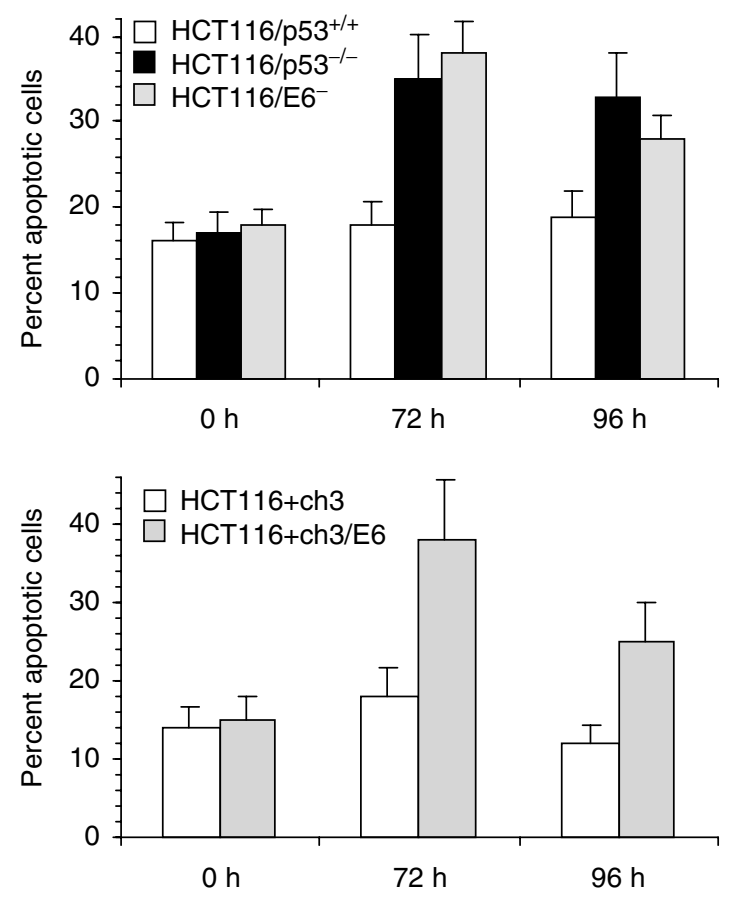

Time after the beginning of exposure to amifostine

Figure 2 Effect of p53 protein on amifostine-induced apoptosis HCTII 6 cells were exposed to amifostine for $24 \mathrm{~h}$, and the fraction of apoptotic cells was determined by supravital fluorescence microscopy at 72 and $96 \mathrm{~h}$ after the beginning of exposure to amifostine. Upper panel: white

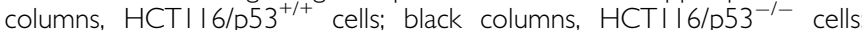
shaded columns, HCTII6/E6 cells. Lower panel: white columns, HCTII6+ch3 cells; shaded columns, HCTII6+ch3/E6 cells. Columns and bars represent mean \pm s.d. of three independent experiments each performed with triplicate cultures.

and -deficient HCT116 cells were exposed to increasing concentrations of amifostine for $24 \mathrm{~h}$. The number of colonies was assessed after 10-14 days. In HCT116 cells, deletion of the p53 gene by targeted homologous deletion resulted in a $1.4 \pm 0.2$-fold increase in amifostine sensitivity, as quantitated by the ratio of the IC $_{50}$ values (mean \pm s.d., $n=3, P<0.05$ by a two-sided $t$-test). Similarly, degradation of p53 protein by E6 resulted in a $1.6 \pm 0.2-$ fold increase in amifostine sensitivity (mean \pm s.d., $n=3, P<0.05$ by a two-sided $t$-test). In mismatch repair-proficient HCT116+ch3 cells, degradation of p53 protein by E6 resulted in a 1.9 \pm 0.2 -fold increase in sensitivity to amifostine (mean \pm s.d., $n=3, P<0.05$ by a two-sided $t$-test).

\section{Effect of p53 protein on amifostine-induced apoptosis}

Supravital fluorescence microscopy was used to quantitate apoptotic cells (Figure 2). HCT116/p $53^{+/+}$, HCT116/p $53^{-/-}$, and HCT116/E6 cells were exposed to $3.8 \mathrm{~mm}$ amifostine for $24 \mathrm{~h}$, a schedule that corresponded to an $\mathrm{IC}_{50}$ in $\mathrm{HCT} 116 / \mathrm{p} 53^{+/+}$cells. HCT116+ch3 and HCT116+ch3/E6 cells were exposed to $4.9 \mathrm{~mm}$ amifostine for $24 \mathrm{~h}$, which corresponded to an $\mathrm{IC}_{50}$ in $\mathrm{HCT} 116+\mathrm{ch} 3$ cells. The fraction of apoptotic cells was determined at 72 and $96 \mathrm{~h}$ after the beginning of exposure to amifostine. Equimolar concentrations of amifostine are expected to result in the same extent of cellular injury in cells that differ only with respect to p53 status. Therefore, any differential effect in amifostine-induced apoptosis is conjectured to be the result of p53-mediated, differential processing of cellular damage. In HCT116 cells, deletion of the $p 53$ gene by targeted recombination resulted in an increase in amifostine-induced apoptosis by $1.9 \pm 0.2-$ and $1.8 \pm 0.2$-fold at 72 and $96 \mathrm{~h}$ after the beginning of exposure to amifostine, respectively (mean \pm s.d., $n=3, P<0.05$ by a two-sided $t$-test for the comparison of p53-proficient $v s$-deficient cells). Similarly, degradation of p53 protein by E6 resulted in an increase in amifostine-induced apoptosis by $2.1 \pm 0.2$-fold and $1.5 \pm 0.2$-fold at 72 and $96 \mathrm{~h}$ after the beginning of exposure to amifostine, respectively (mean \pm s.d., $n=3, P<0.05$ by a two-sided $t$-test for the comparison of $\mathrm{p} 53$-proficient $v s$-deficient cells). In mismatch repair-proficient HCT116+ch3 cells, E6-mediated degradation of p53 protein resulted in an increase in amifostine-induced apoptosis by $1.8 \pm 0.2$ - and $2.0 \pm 0.2$ - at 72 and $96 \mathrm{~h}$, respectively (mean \pm s.d., $n=3, \quad P<0.05$ by a two-sided $t$-test for the comparison of p53-proficient $v s$-deficient cells).

\section{Effect of p53 protein on cell cycle arrest induced by amifostine}

HCT116/p53 $3^{+/+}$and HCT116/p53 $3^{-/-}$cells were exposed to $3.8 \mathrm{~mm}$ amifostine for $24 \mathrm{~h}$, which corresponded to an IC $_{50}$ in HCT116/ p53 $3^{+/+}$cells. HCT116+ch 3 and HCT116+ch3/E6 cells were exposed to $4.9 \mathrm{~mm}$ amifostine for $24 \mathrm{~h}$, which corresponded to an $\mathrm{IC}_{50}$ in HCT116+ch3 cells. In p53-proficient HCT116/p53 $3^{+/+}$and HCT116+ch3 cells, treatment with amifostine caused a G1 arrest that peaked at $24 \mathrm{~h}$ (Figure 3). However, in p53-deficient HCT116/ p53 $3^{-1-}$ and HCT116+ch3/E6 cells, amifostine failed to cause a G1 arrest, indicating that the G1 arrest induced by amifostine is dependent on p53 protein. Amifostine also caused a G2/M arrest, which occurred in both p53-proficient and -deficient cells, indicating that the $\mathrm{G} 2 / \mathrm{M}$ arrest is mediated via a pathway that is independent of p53 protein.

\section{Effect of p53 protein on amifostine-induced cytoprotection}

To determine whether p53 protein regulates the cytoprotective properties of amifostine, we investigated the effect of amifostine on paclitaxel toxicity in p53-proficient and -deficient cells (Figure 4). HCT116 cells were exposed to $20 \mathrm{~nm}$ paclitaxel for $24 \mathrm{~h}$ in the absence or presence of amifostine. Amifostine-treated cells were pretreated with $100 \mu \mathrm{M}$ amifostine for $30 \mathrm{~min}$ and subsequently exposed to amifostine and paclitaxel for $24 \mathrm{~h}$. At this concentration, amifostine is nontoxic; however, even at low concentrations, amifostine has important biologic effects, such as induction of p53 protein, a finding that occurs at concentrations as low as $50 \mu \mathrm{m}$ (North et al, 2000). At $48 \mathrm{~h}$ after the beginning of drug exposure, cells were stained with acridine orange and ethidium bromide, and the fraction of apoptotic cells was determined by supravital fluorescence microscopy. Amifostine protected p53-proficient 

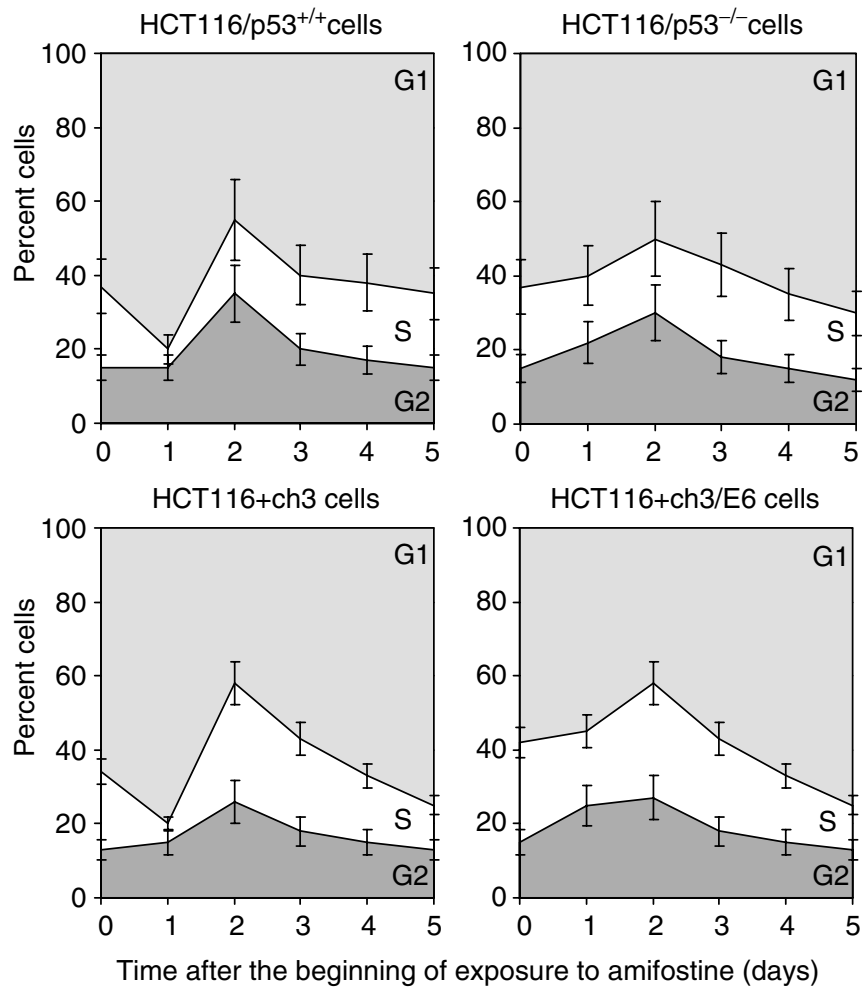

Figure 3 Effect of p53 protein on cell cycle arrest induced by amifostine. HCTII6 cells were exposed to amifostine for $24 \mathrm{~h}$ and cell cycle phase distribution was determined by flowcytometry. Data points represent mean \pm s.d. of three independent experiments.
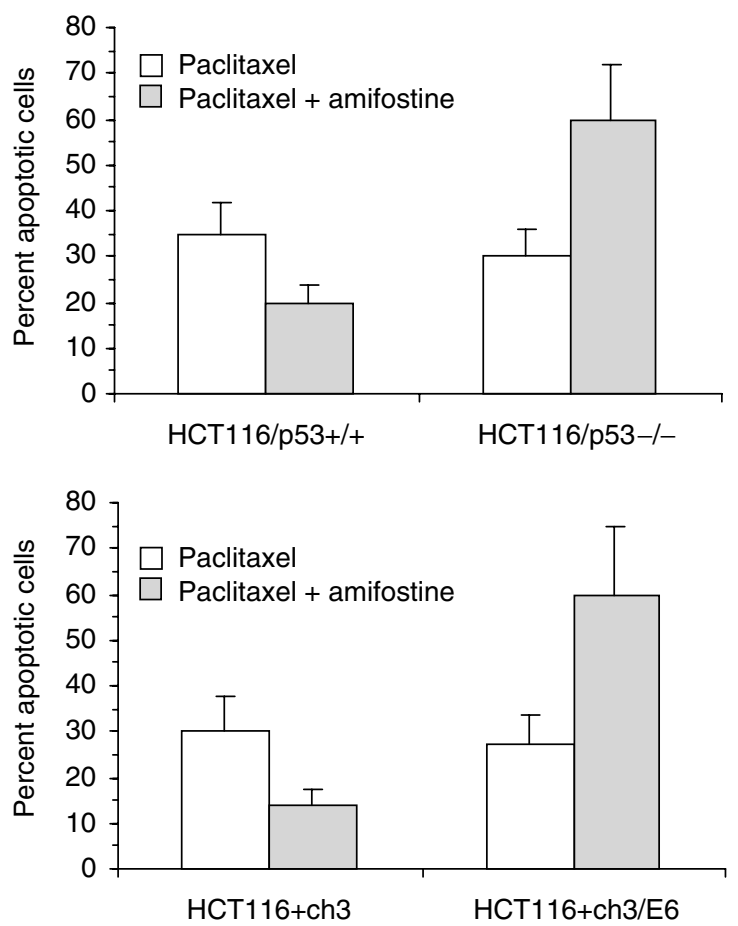

Figure 4 Effect of p53 protein on amifostine-induced cytoprotection. HCTII6 cells were exposed to paclitaxel for $24 \mathrm{~h}$ in the absence or presence of amifostine. The fraction of apoptotic cells was determined by supravital fluorescence microscopy at $48 \mathrm{~h}$ after the beginning of drug exposure. Open columns, cells treated with paclitaxel alone; shaded columns, cells treated with paclitaxel and amifostine. Columns and bars represent mean \pm s.d. of three independent experiments.

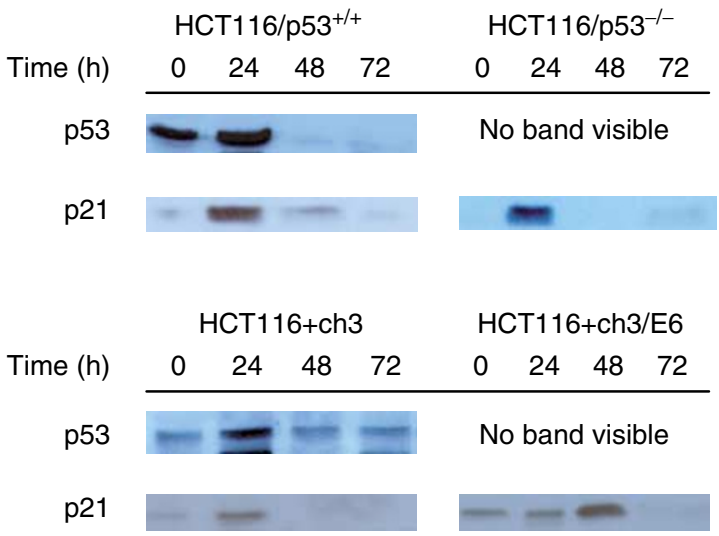

Figure 5 Effect of amifostine on the expression of $p 53$ protein and p2 I protein. HCTII 6 cells were exposed to amifostine for $24 \mathrm{~h}$ and cellular proteins were analysed by Western blotting at various points in time after the beginning of exposure to amifostine. Amifostine induced the expression of $\mathrm{p} 53$ protein in $\mathrm{p} 53$-proficient cells and the expression of $\mathrm{p} 2 \mathrm{I}$ protein in p53-proficient and-deficient cells.

HCT $116 / \mathrm{p} 53^{+/+}$and HCT116+ch3 cells from the cytotoxicity of paclitaxel and reduced paclitaxel-induced apoptosis by $1.75 \pm 0.2$ fold (mean \pm s.d., $n=3, P<0.05$ by a two-sided $t$-test) and $2.0 \pm 0.2$-fold $(P<0.05)$, respectively. However, amifostine failed to protect $\mathrm{p} 53$-deficient cells from the cytotoxicity of paclitaxel, indicating that the cytoprotective effect of amifostine is p53-dependent. Interestingly, in p53-deficient HCT116/p53 $3^{-l-}$ and HCT116+ch3/E6 cells, amifostine enhanced paclitaxel-induced apoptosis by $2.1 \pm 0.2$-fold (mean \pm s.d., $n=3, P<0.05$ by a twosided $t$-test) and $2.2 \pm 0.2$-fold $(P<0.05)$, respectively.

\section{Effect of amifostine on the expression of $\mathrm{p} 53$ protein and $\mathrm{p} 21$ protein}

To further investigate the role of $\mathrm{p} 53$ protein and $\mathrm{p} 21$ protein on amifostine-induced apoptosis and cell cycle progression, we determined the effect of amifostine on the expression of p53 protein and p21 protein in p53-proficient and -deficient cells (Figure 5). HCT116/p53 $3^{+/+}$and HCT116/p53 $3^{-/-}$cells were exposed to $3.8 \mathrm{~mm}$ amifostine for $24 \mathrm{~h}$, which corresponded to an $\mathrm{IC}_{50}$ in HCT $116 /{\mathrm{p} 53^{+/+}}^{+/ 1}$ cells. HCT116+ch3 and HCT116+ch3/E6 cells were exposed to $4.9 \mathrm{~mm}$ amifostine for $24 \mathrm{~h}$, corresponding to an $\mathrm{IC}_{50}$ in HCT116+ch3 cells. In p53-proficient cells, amifostine caused a rapid induction of $\mathrm{p} 53$ protein, which, like the amifostine-induced G1 arrest, peaked at $24 \mathrm{~h}$.

In addition, amifostine caused a rapid induction of $\mathrm{p} 21$ protein. Induction of p21 protein occurred in both p53-proficient and -deficient cells, indicating that the induction of p21 protein in response to amifostine is independent of p53 protein. In p53-deficient cells, amifostine induced the expression of p21 protein without causing a G1 arrest, indicating that overexpression of $\mathrm{p} 21$ protein in response to amifostine was not sufficient to arrest cells in the G1 phase of the cell cycle.

\section{DISCUSSION}

The prodrug amifostine and its active metabolite WR-1065 have been shown to have differential effects on malignant $v s$ nonmalignant tissue. For instance, amifostine protects normal tissues from the toxic effects of ionising radiation and chemotherapeutic agents, but has either no effect or enhances the antitumour effects of these agents (van der Vijgh and Peters, 1994; Taylor et al, 1997; Capizzi, 1999a; Shen et al, 2001). The mechanisms by which amifostine preferentially protects normal cells are poorly 
understood. Selective protection of normal tissue by amifostine has been associated with activation of a p53-dependent pathway, and amifostine has been shown to bind to p53 protein and to enhance transactivation of downstream genes (Shen et al, 2001).

We now report on the effects of p53 protein on the cellular pharmacology of amifostine in two sets of matched HCT116 cell lines that differ in p53 status. In the first set, the $p 53$ gene was deleted by homologous recombinant deletion; in the second set, the p53 protein was degraded by high-level expression of human papillomavirus E6 protein. In both sets of HCT116 cell lines, amifostine selectively protected p53-proficient cells from the cytotoxicity of paclitaxel. Since normal tissue is p53-proficient, this finding could, at least in part, explain the observation that amifostine protects normal tissues from the toxic effects of ionising radiation and chemotherapeutic agents but fails to protect malignant tissue, which is often p53-deficient. Many solid tumours differ from nonmalignant tissue in that they express defective forms of p53 protein itself or of the pathways downstream of p53 protein (Sherr and Weber, 2000).

Amifostine is a phosphorylated aminothiol prodrug that is dephosphorylated by membrane-bound alkaline phosphatase to form the active metabolite WR-1065, a free thiol that exhibits cytoprotective activity after being transported into the cell (van der Vijgh and Peters, 1994; Capizzi, 1999b). Preferential protection of normal cells has been associated with higher activity of membranebound alkaline phosphatase in normal endothelium and normal tissue, compared to neovascular endothelium and tumour tissue (Manheimer and Seligman, 1948; Romanul and Bannister, 1962). However, recent observations indicate that differences in the expression of alkaline phosphatase and cellular transport between normal and tumour tissue cannot entirely account for the selectivity with which amifostine protects normal tissue. For instance, the dephosphorylated metabolite of amifostine, WR1065, which penetrates equally well into cultured cancer and noncancer cells, has also been found to have a preferential radioprotective effect on human diploid fibroblasts, as compared to HT-1080 fibrosarcoma cells (Zhang et al, 1992).

In spite of protecting p53-proficient cells from the cytotoxicity of paclitaxel, amifostine sensitised p53-deficient HCT116 cells to paclitaxel. Similarly, amifostine has been shown to sensitise $\mathrm{CaCl}$ melanoma cells to paclitaxel in a p53-dependent manner (Shen et al, 2001). In addition, amifostine has been shown to protect MRC-5 human lung fibroblasts from paclitaxel-induced cytotoxicity and to enhance paclitaxel cytotoxicity in A427 lung cancer cells (Taylor et al, 1997). Although A427 cells express p53 protein (Soini et al, 2001), these cells fail to arrest in response to DNA damage (Strobeck et al, 2001), indicating that the p53 pathway is inactive as a result of a defect in p53 protein itself or in a pathway downstream of $\mathrm{p} 53$ protein. The mechanisms by which amifostine enhances drug sensitivity in cells with a defective p53 pathway are not well understood. Interestingly, in amifostine-treated A427 cells, enhanced sensitivity to paclitaxel has been associated with increased formation of DNA single-strand breaks (Taylor et al, 1997).

\section{REFERENCES}

Bohuslavizki KH, Klutmann S, Brenner W, Mester J, Henze E, Clausen M (1998) Salivary gland protection by amifostine in high-dose radioiodine treatment: results of a double-blind placebo-controlled study. J Clin Oncol 16: $3542-3549$

Boyer JC, Umar A, Risinger JI, Lipford JR, Kane M, Yin S, Barrett JC, Kolodner RD, Kunkel TA (1995) Microsatellite instability, mismatch repair deficiency, and genetic defects in human cancer cell lines. Cancer Res 55: 6063-6070

Brizel DM, Wasserman TH, Henke M, Strnad V, Rudat V, Monnier A, Eschwege F, Zhang J, Russell L, Oster W, Sauer R (2000) Phase III
In amifostine-treated cells, p53 protein also plays an important role in regulating progression through the cell cycle. Amifostine caused a G2 arrest in both p53-proficient and -deficient cells, indicating that the amifostine-induced G2 arrest is independent of p53 protein. In addition, amifostine induced the expression of $\mathrm{p} 21$ protein via a p53-independent pathway, a finding that is compatible with a role of p21 protein in amifostine-induced G2 arrest. Indeed, p21 protein has been shown to inhibit phosphorylation of Cdc2 and to enforce G2 arrest (Smits et al, 2000).

Amifostine also caused a G1 arrest, which, in contrast to the G2 arrest, occurred only in p53-proficient cells, indicating that the G1 arrest is dependent on p53 protein. In p53-proficient cells, both the G1 arrest and the induction of p53 protein peaked at $24 \mathrm{~h}$ after the beginning of exposure to amifostine, a finding consistent with the notion that the G1 arrest induced by amifostine is mediated via a p53-dependent pathway. Since amifostine induced the expression of $\mathrm{p} 21$ protein in both p53-proficient and -deficient cells but caused a G1 arrest only in p53-proficient cells, induction of p21 protein alone was not sufficient to sustain a G1 arrest after treatment with amifostine. In addition to regulating the transcription of the $p 21$ gene, p53 protein has been shown to regulate the transcription of genes encoding other downstream proteins, including other members of the Cip/Kip family, such as $\mathrm{p} 27^{\mathrm{Kip} 1}$ and p57 ${ }^{\mathrm{Kip} 2}$ (Shapiro and Harper, 1999). Like p21 protein, $\mathrm{p} 27^{\mathrm{Kip} 1}$ and $\mathrm{p} 57^{\mathrm{Kip} 2}$ proteins have also been shown to form complexes with cyclin E-CDK2 and to promote CDK2 inhibition and G1 arrest (Shapiro and Harper, 1999). Thus, the observation that overexpression of $\mathrm{p} 21$ protein was not sufficient to sustain a G1 arrest in amifostine-treated cells suggests that amifostine induced the expression of one or more other cell cycle inhibitors downstream of $\mathrm{p} 53$ protein.

In HCT116 cells, amifostine, a cytoprotective agent, also has the potential to induce apoptosis. In the presence of p53 protein, HCT116 cells exhibited low-level resistance to amifostine, indicating that $\mathrm{p} 53$ protein protected cells from amifostine-induced apoptosis. The degree of resistance to amifostine conferred by p53 protein was modest, in the range of 1.5-2-fold, and the biologic relevance of such relatively small degrees of resistance is poorly understood. Amifostine triggered apoptotic cell death at concentrations that are only slightly above the plasma concentrations achieved in clinical studies (Shaw et al, 1986, 1988), indicating that this observation may have clinical relevance.

Taken together, our findings indicate that p53 protein plays an important role in regulating the cellular response to amifostine and identify p53 protein as a mechanism of resistance to amifostineinduced apoptosis and as a mechanism of amifostine-induced G1 arrest and cytoprotection.

\section{ACKNOWLEDGEMENTS}

This work was supported by grants from the American Cancer Society, Cap Cure, the Colleen Gilbert Foundation sponsored by Moves Fitness, and the Clayton Foundation for Research. randomized trial of amifostine as a radioprotector in head and neck cancer. J Clin Oncol 18: 3339-3345

Buntzel J, Kuttner K, Frohlich D, Glatzel M (1998) Selective cytoprotection with amifostine in concurrent radiochemotherapy for head and neck cancer. Ann Oncol 9: 505-509

Bunz F, Hwang PM, Torrance C, Waldman T, Zhang Y, Dillehay L, Williams J, Lengauer C, Kinzler KW, Vogelstein B (1999) Disruption of p53 in human cancer cells alters the responses to therapeutic agents. J Clin Invest 104: $263-269$ 
Capizzi RL (1999a) Clinical status and optimal use of amifostine. Oncology (Huntingt) 13: 47-59; discussion 63, 67

Capizzi RL (1999b) The preclinical basis for broad-spectrum selective cytoprotection of normal tissues from cytotoxic therapies by amifostine. Semin Oncol 26: $3-21$

Capizzi RL, Oster W (2000) Chemoprotective and radioprotective effects of amifostine: an update of clinical trials. Int J Hematol 72: 425-435

Carethers JM, Pham TT (2000) Mutations of transforming growth factor beta 1 type II receptor, BAX, and insulin-like growth factor II receptor genes in microsatellite unstable cell lines. In Vivo 14: 13-20

Davis TW, Wilson-Van Patten C, Meyers M, Kunugi KA, Cuthill S, Reznikoff C, Garces C, Boland CR, Kinsella TJ, Fishel R, Boothman DA (1998) Defective expression of the DNA mismatch repair protein, MLH1, alters G2-M cell cycle checkpoint arrest following ionizing radiation. Cancer Res 58: $767-778$

Dean PN, Jett JH (1974) Mathematical analysis of DNA distributions derived from flow microfluorometry. J Cell Biol 60: 523-530

DeNeve WJ, Everett CK, Suminski JE, Valeriote FA (1988) Influence of WR2721 on DNA cross-linking by nitrogen mustard in normal mouse bone marrow and leukemia cells in vivo. Cancer Res 48: 6002-6005

Grdina DJ, Constantinou A, Shigematsu N, Murley JS (1994) Inhibition of topoisomerase II alpha activity in CHO K1 cells by 2-[(aminopropyl)amino] ethanethiol (WR-1065). Radiat Res 138: 44-52

Hawn MT, Umar A, Carethers JM, Marra G, Kunkel TA, Boland CR, Koi M (1995) Evidence for a connection between the mismatch repair system and the G2 cell cycle checkpoint. Cancer Res 55: 3721 - 3725

Kemp G, Rose P, Lurain J, Berman M, Manetta A, Roullet B, Homesley H, Belpomme D, Glick J (1996) Amifostine pretreatment for protection against cyclophosphamide-induced and cisplatin-induced toxicities: results of a randomized control trial in patients with advanced ovarian cancer. J Clin Oncol 14: $2101-2012$

Koi M, Umar A, Chauhan DP, Cherian SP, Carethers JM, Kunkel TA, Boland CR (1994) Human chromosome 3 corrects mismatch repair deficiency and microsatellite instability and reduces $N$-methyl- $N^{\prime}$-nitro$\mathrm{N}$-nitrosoguanidine tolerance in colon tumour cells with homozygous hMLH1 mutation. Cancer Res 54: $4308-4312$

List AF, Brasfield F, Heaton R, Glinsmann-Gibson B, Crook L, Taetle R, Capizzi R (1997) Stimulation of hematopoiesis by amifostine in patients with myelodysplastic syndrome. Blood 90: 3364-3369

List AF, Heaton R, Glinsmann-Gibson B, Capizzi RL (1998) Amifostine stimulates formation of multipotent and erythroid bone marrow progenitors. Leukemia 12: $1596-1602$

Liu SC, Murley JS, Woloschak G, Grdina DJ (1997) Repression of c-myc gene expression by the thiol and disulfide forms of the cytoprotector amifostine. Carcinogenesis 18: $2457-2459$

Liu T, Liu Y, He S, Zhang Z, Kligerman MM (1992) Use of radiation with or without WR-2721 in advanced rectal cancer. Cancer 69: 2820-2825

Manheimer LH, Seligman AM (1948) Improvement in the method for the histochemical demonstration of alkaline phosphatase and its use in a study of normal and neoplastic tissues. J Natl Cancer Inst 9: 181 - 191

Maurici D, Monti P, Campomenosi P, North S, Frebourg T, Fronza G, Hainaut P (2001) Amifostine (WR2721) restores transcriptional activity of specific p53 mutant proteins in a yeast functional assay. Oncogene 20: $3533-3540$

McGahon AJ, Martin SM, Sissonnette RP, Mahboubi A, Shi Y, Mogil RJ, Nishioka WK, Greeen DR (1995) The end of the cell line: methods for the study of apoptosis. In Cell Death, Schwarz LM, Osborne BA (eds), Vol. 46. San Diego: Academic Press.
Murley JS, Constantinou A, Kamath NS, Grdina DJ (1997) WR-1065, an active metabolite of the cytoprotector amifostine, affects phosphorylation of topoisomerase II alpha leading to changes in enzyme activity and cell cycle progression in CHO AA8 cells. Cell Prolif 30: 283-294

North S, El-Ghissassi F, Pluquet O, Verhaegh G, Hainaut P (2000) The cytoprotective aminothiol WR1065 activates p21waf-1 and down regulates cell cycle progression through a p53-dependent pathway. Oncogene 19: 1206 - 1214

Papadopoulos N, Nicolaides NC, Wei YF, Ruben SM, Carter KC, Rosen CA, Haseltine WA, Fleischmann RD, Fraser CM, Adams MD, Lee EJ, Gerhold M, Palmer MW, Christen RD (1994) Mutation of a mutL homolog in hereditary colon cancer. Science 263: $1625-1629$

Romanul RC, Bannister RG (1962) Localized areas of high alkaline phophatase activity in endothelium of arteries. Nature 195: 611-612

Shapiro GI, Harper JW (1999) Anticancer drug targets: cell cycle and checkpoint control. J Clin Invest 104: 1645-1653

Shaw LM, Glover D, Turrisi A, Brown DQ, Bonner HS, Norfleet AL, Weiler C, Glick JH, Kligerman MM (1988) Pharmacokinetics of WR-2721. Pharmacol Ther 39: 195-201

Shaw LM, Turrisi AT, Glover DJ, Bonner HS, Norfleet AL, Weiler C, Kligerman MM (1986) Human pharmacokinetics of WR-2721. Int J Radiat Oncol Biol Phys 12: $1501-1504$

Shen H, Chen ZJ, Zilfou JT, Hopper E, Murphy M, Tew KD (2001) Binding of the aminothiol WR-1065 to transcription factors influences cellular response to anticancer drugs. J Pharmacol Exp Ther 297: 1067-1073

Sherr CJ, Weber JD (2000) The ARF/p53 pathway. Curr Opin Genet Dev 10: $94-99$

Smits VA, Klompmaker R, Vallenius T, Rijksen G, Makela TP, Medema RH (2000) p21 inhibits Thr161 phosphorylation of Cdc2 to enforce the G2 DNA damage checkpoint. J Biol Chem 275: 30638 - 30643

Snyder RD, Grdina DJ (2000) Further evidence that the radioprotective aminothiol, WR-1065, catalytically inactivates mammalian topoisomerase II. Cancer Res 60: 1186-1188

Soini Y, Kahlos K, Napankangas U, Kaarteenaho-Wiik R, Saily M, Koistinen P, Paaakko P, Holmgren A, Kinnula VL (2001) Widespread expression of thioredoxin and thioredoxin reductase in non-small cell lung carcinoma. Clin Cancer Res 7: 1750-1757

Strobeck MW, Reisman DN, Gunawardena RW, Betz BL, Angus SP, Knudsen KE, Kowalik TF, Weissman BE, Knudsen ES (2001) Compensation of BRG-1 function by Brm: insight into the role of the core SWI/SNF subunits in RB-signaling. J Biol Chem 21: 21

Taylor CW, Wang LM, List AF, Fernandes D, Paine-Murrieta GD, Johnson CS, Capizzi RL (1997) Amifostine protects normal tissues from paclitaxel toxicity while cytotoxicity against tumour cells is maintained. Eur J Cancer 33: $1693-1698$

Treskes M, van der Vijgh WJ (1993) WR2721 as a modulator of cisplatinand carboplatin-induced side effects in comparison with other chemoprotective agents: a molecular approach. Cancer Chemother Pharmacol 33: $93-106$

van der Vijgh WJ, Peters GJ (1994) Protection of normal tissues from the cytotoxic effects of chemotherapy and radiation by amifostine (Ethyol): preclinical aspects. Semin Oncol 21: 2-7

Woloschak GE, Paunesku T, Chang-Liu CM, Grdina DJ (1995) Expression of thymidine kinase messenger RNA and a related transcript is modulated by radioprotector WR1065. Cancer Res 55: 4788-4792

Zhang X, Lai PP, Taylor YC (1992) Differential radioprotection of cultured human diploid fibroblasts and fibrosarcoma cells by WR1065. Int J Radiat Oncol Biol Phys 24: 713-719 